\title{
Pengaruh Ekstrak Buah Pare (Momordica charantia) Terhadap Titer Antibodi Ayam Broiler yang Divaksin Newcastle Disease
}

\author{
(THE INFLUENCE OF PARE (Momordica charantia) FRUIT EXTRACTS ON THE \\ ANTIBODY TITER OF CHICKEN BROILER IN THE Newcastle Disease VACCINE)
}

\author{
Siti Komariyah $^{1 *}$, Jola Rahmahani ${ }^{2}$, Bodhi Agustono ${ }^{3}$ \\ ${ }^{1}$ Bachelor of Veterinary Medicine, \\ ${ }^{2}$ Department of Veterinary Microbiology, \\ ${ }^{3}$ Department of Animal Husbandry, \\ Faculty of Veterinary Medicine, Universitas Airlangga, \\ UNAIR C-Campus Mulyorejo, Surabaya, Jawa Timur, Indonesia, 60115 \\ Telp. (031)5993016, Fax. (031)5993015 \\ *Corresponding author: siti.komariyah-2014@ fkh.unair.ac.id
}

\begin{abstract}
Abstrak
Tujuan dari penelitian ini untuk mengetahui pengaruh pemberian ekstrak buah pare (Momordica charantia) terhadap titer antibodi ayam broiler yang di vaksin ND berdasarkan hasil titer antibodi dengan menggunakan uji Hemaglution Inhibition (HI). Metode dalam penelitian ini adalah menggunakan metode Rancangan Acak Lengkap (RAL), sehingga jumlah sampel untuk 5 perlakuan adalah 50 ekor ayam broiler. Data hasil pemeriksaan uji HI dianalisa secara statistik menggunakan ANOVA dengan menggunakan software SPSS v22. Jika terdapat perbedaan pada masing-masing kelompok perlakuan maka dilanjutkan dengan Uji Duncan untuk melihat ada tidaknya perbedaan yang nyata antara kelompok perlakuan dengan kelompok kontrol. Titer protektif terhadap ND untuk ayam adalah $2^{6}$ berarti jika di bawah nilai tersebut, maka antibodi di dalam tubuh ayam tidak dapat melindungi ayam dari virus, begitu juga sebaliknya, jika $\geq 2^{6}$ maka antibodi di dalam tubuh ayam dapat melindungi tubuh ayam dari infeksi virus. Hasil Penelitian ini kelompok P0 berbeda nyata $(\mathrm{p}<0,05)$ dengan kelompok P1, P2, P3, P4 hal tersebut karena pada kelompok P0 merupakan perlakuan tanpa vaksin dan ekstrak buah pare. Kelompok P1 tidak berbeda nyata (p>0,05) dengan kelompok P2, P3, P4. Kelompok P2 dan P3 tidak berbeda nyata $(p>0,05)$ dengan kelompok P1 dan P4 dan memiliki ratan titer antibodi yang sama. Kelompok P4 tidak berbeda nyata dengan kelompok P1, P2, P3 namun memiliki titer yang lebih tinggi. Kesimpulan dari hasil penelitian adalah pemberian ekstrak buah pare tidak berpengaruh nyata terhadap titer antibodi ayam broiler yang di vaksin Newcastle disease.
\end{abstract}

Kata kunci: buah pare, titer antibodi, ayam broiler, Newcastle Disease

\begin{abstract}
The aims of this research were to examine the effect of giving extract pare (Momordica charantia) to broiler antibody titer in ND vaccine based on antibody titer result by using Hemaglution Inhibition (HI) test. The method in this research is using the Completely Randomized Design (RAL) method, so the number of samples for 5 treatments is 50 broiler chickens. The HI test results were analyzed statistically using ANOVA using SPSS v22 software. If there is a difference in each treatment group then proceed with Duncan Test to see whether there is a real difference between the treatment group and the control group. The protective titer against ND for the chicken is $2^{6}$ means if, below that value, the antibodies in the body chickens cannot protect chickens from viruses, and vice versa, if $\geq 2^{6}$ then antibodies in the chicken body can protect the chicken body from virus infection. The results of this study were significantly different $(p<0,05)$ with P1, P2, P3, P4 group because PO group was treated without vaccine and pare extract. Group P1 was not significantly different $(p>0,05)$ with group P2, P3, P4. The groups $P 2$ and P3 were not significantly different $(p>0,05)$ with the P1 and P4 groups and had the same degree of antibody titer. The P4 group was not significantly different from Pl, P2, P3 but had higher titers. The conclusion from the research result is giving of pare extract did not have a real effect to broiler antibody titer in vaccine Newcastle disease.
\end{abstract}




\section{PENDAHULUAN}

Newcastle Disease (ND) disebabkan oleh Paramyxovirus tipe-1 (PMV-1) yang termasuk dalam golongan Paramyxoviridae (Miller et al., 2010). Penyakit ND merupakan masalah besar bagi dunia peternakan, karena dapat menimbulkan morbiditas dan mortalitas yang tinggi (mencapai $100 \%$ ), waktu penyebarannya yang sangat cepat dan bersifat kompleks, sehingga menunjukkan adanya variasi dalam bentuk dan keparahan penyakit. Penyakit ND masih merupakan penyakit endemik di Indonesia, yang ditandai dengan kejadian penyakit yang ditemukan sepanjang tahun (Tabbu, 2000).

Pencegahan infeksi virus ND di Indonesia difokuskan pada biosekuriti dan biosafety untuk mengurangi gejala penyakit yang endemis (Shunlin et al., 2009). Berbagai program telah dilakukan oleh pemerintah dalam upaya mencegah penyebaran penyakit ND. Sampai saat ini belum ada obat yang efektif untuk mengatasi infeksi virus ND. Frekuensi vaksinasi ND awalnya bertujuan untuk mencegah penyakit ND, namun fakta dilapang penyakit ND masih terjadi, meski kasus penyakit sporadis pada ayam yang telah divaksinasi. Beberapa tahun terakhir, wabah ND masih terjadi pada unggas yang telah divaksinasi (Adi et al., 2010; Dharmayanti et al., 2014; Patti et al., 2007; dan Xiao et al., 2012).

Beberapa jenis tanaman obat dapat menjadi alternatif pencegahan maupun pengobatan. Tanaman obat di Indonesia pernah dilaporkan memiliki potensi memiliki kandungan senyawa imunostimulan. Penggunaan senyawa bahan alam dalam pemanfaatannya perlu dioptimalkan, maka pada penelitian ini digunakan ekstrak buah pare (Momordica charatia). Buah pare mengandung saponin, flavonoid, steroid/triterpenoid, karbohidrat, momordisin, alkaloid, vitamin A, vitamin B, Vitamin C, asam fenolat, dan karatenoid. Penelitian membuktikan bahwa secara laboratoris senyawa flavonoid dapat meningkatkan produksi IL-2 dan meningkatkan proliferasi dan diferensiasi limfosit sel T, sel B dan sel NK (Saifulhaq, 2009).
Penelitian sebelumnya menyatakan bahwa buah pare dapat menjadi imunomodulator pada penderita positif HIV (Chunthorng-Orn et al., 2012 dan Fang et al., 2012). Penelitian secara in vivo, ekstrak buah pare menunjukkan kemampuan untuk meningkatkan ketahanan terhadap infeksi virus dan memberikan efek imunostimulan pada manusia dan hewan (meningkatkan produksi sel interferon dan aktivitas sel NK) (Gupta et al., 2011).

Berdasarkan latar belakang di atas, maka dilakukan penelitian untuk mengetahui pengaruh ekstrak buah pare (Momordica charantia) sebagai imunostimulan titer antibodi ayam broiler yang divaksin ND.

\section{METODE PENELITIAN}

\section{Alat dan bahan}

Bahan yang digunakan dalam penelitian ini adalah buah pare, ayam broiler, vaksin ND live (Lasota), alkohol, etanol 96\%, PZ, antigen ND 4 HA unit, eritrosit ayam $0,5 \%$. kebutuhan harian ayam seperti pakan dan minum, sekam sebagai alas.

Alat yang digunakan dalam penelitian ini antara lain: mikroshaker, freezer, waterbath, centrifuge, tabung centrifuge, spuit $3 \mathrm{cc}$, pipet, gelas ukur, erlenmeyer, cool box, tabung venoject, pinset dan gunting, mikropipet $25 \mu \mathrm{l}$ dan $50 \mu \mathrm{l}$, mikroplate bentuk (V) atau (U), yellowtip, microtube, tabung EDTA.

\section{Persiapan dan Pembuatan ekstrak buah pare}

Serbuk dari buah pare tersebut dimasukkan ke dalam labu ekstraktor dan dituangi etanol 96\% sebanyak 1 liter sampai terendam semua. Labu ekstraktor diletakkan pada mesin shaker dan dibiarkan selama $4 \times 24$ jam dalam suhu kamar. Larutan ekstrak disaring dan filtrate yang didapatkan dipindahkan dalam cawan penguap kemudian dimasukkan dalam vaccum evaporator dengan suhu $40-60^{\circ} \mathrm{C}$ sampai didapatkan cairan ekstrak buah pare yang kental dan berwarna kecoklatan.

\section{Pemberian Vaksin dan Ekstrak Buah Pare}


Pemberian vaksin ND live (Lasota) dilakukan secara intramuskular. Pemberian ekstrak buah pare dosis yang digunakan adalah dosis $150 \mathrm{mg} / \mathrm{L}, 300 \mathrm{mg} / \mathrm{L}, 450 \mathrm{mg} / \mathrm{L}$.

\section{Pengambilan Darah Ayam}

Pengambilan darah dilakukan pada daerah pembuluh darah vena brachialis, terlebih dahulu harus diusap kapas beralkohol $70 \%$ untuk menghindari kontaminasi dan membasahi bulubulu yang menghalangi area vena dengan menggunakan spuit $3 \mathrm{cc}$, ukuran jarum 23G.

\section{Uji 4 Hemaglutinasi (HA) Unit}

Mengisi microplate dengan $25 \mu \mathrm{lPZ}$ mulai lubang 1-5 pada baris A dan B (titrasi duplikat). Alat yang digunakan untuk mengisi lubang microplate dengan $\mathrm{PZ}$ adalah multichannel pipet $25 \mu 1$. Microplate diisi pada lubang nomor 1 baris A dan B dengan antigen $25 \mu \mathrm{l}$ dan alat yang digunakan adalah multichannel pipet $25 \mu \mathrm{l}$. Antigen dan PZ dicampurkan pada lubang nomor 1, kemudian dipindahkan ke lubang berikutnya, demikian seterusnya sampai lubang nomor 4 dan 5 digunakan sebagai kontrol eritrosit (tanpa antigen). Semua lubang ditambahkan dengan $50 \mu \mathrm{l}$ eritrosit ayam $0,5 \%$ selanjutnya microplate digoyangkan dan diinkubasi pada suhu kamar selama 30, kemudian dibaca titernya. (Ernawati, 2008).

Titer 4 HA Unit: terjadi hemaglutinasi sampai lubang no. 2, jika hemaglutinasi terjadi sampai lubang no. 3 berarti harus diencerkan sebanyak dua kali.

\section{Uji Hemaglutinasi Inhibisi (HI)}

Lubang microplate diisi dengan $25 \mu 1 \mathrm{PZ}$ menggunakan mikropipet $25 \mu 1$, dari lubang no. 1 sampai 12 , lalu lubang no. 1 dan 12 diisi dengan serum, yang diperiksa sebanyak $25 \mu \mathrm{l}$ dengan menggunakan mikropipet $25 \mu$ l. Serum dengan PZ dicampur menggunakan micropipet $25 \mu 1$ pada lubang no.1 dengan cara hisap tiup dengan mikropipet kemudian pindahkan ke lubang berikutnya, demikan seterusnya sampai lubang no.10. Lubang no.1 sampai 10 diisi dengan antigen 4 HAU sebanyak $25 \mu \mathrm{l}$ dengan menggunakan pipet $25 \mu$ l. Microplate diinkubasi pada suhu kamar selama 30 menit. Semua lubang ditambahkan dengan $50 \mu \mathrm{l}$ eritrosit $0,5 \%$

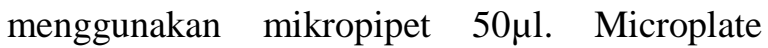
diinkubasi lagi pada suhu kamar selama 30 menit, kemudian dibaca hasil titer (Ernawati, 2008).

Interpretasi hasil: hambatan hemaglutinasi sempurna (100\%) adalah terjadinya pengendapan eritrosit pada dasar lubang mikroplate yang terlihat seperti kontrol eritrosit.

\section{Analisis Data}

Data hasil pemeriksaan uji HI dianalisa secara statistik menggunakan ANOVA dengan menggunakan software SPSS v.22 dan dilanjutkan uji Duncan.

\section{HASIL DAN PEMBAHASAN}

Rataan titer antibodi pada kelompok P0 berbeda nyata $(\mathrm{p}<0,05)$ dengan kelompok $\mathrm{P} 1$, P2, P3, P4, hal tersebut karena pada kelompok P0 merupakan perlakuan tanpa vaksin dan ekstrak buah pare. Hasil analisis menunjukkan bahwa tidak ada perbedaan yang nyata $(\mathrm{p}>0,05)$ antara titer antibodi pada kelompok yang diberi vaksin saja maupun diberi vaksin dan ekstrak buah pare. Pada kelompok P1 tidak berbeda nyata ( $>0$,05) dengan P2, P3, P4. Kelompok P2, P3 tidak berbeda nyata $(p>0,05)$ dengan P1, P4 dan memiliki rataan titer antibodi yang sama dengan P1. Kelompok P4 tidak berbeda nyata nyata $(p>0,05)$ dan memiliki titer antibodi lebih tinggi dibandingkan dengan P1, P2, P3 .

Titer antibodi pasca vaksinasi ND kedua (booster) lebih tinggi dari hasil vaksinasi pertama. Rataan titer antibodi pada kelompok P0 berbeda nyata nyata $(\mathrm{p}<0,05)$ dengan kelompok P1, P2, P3, P4, hal tersebut karena pada kelompok P0 merupakan perlakuan tanpa vaksin dan esktrak buah pare. Hasil analisis menunjukkan bahwa perlakuan diberi vaksin saja tidak berbeda nyata $(p>0,05)$ dengan perlakuan vaksin dan ekstrak buah pare. Kelompok P1 tidak berbeda nyata $(p>0,05)$ dengan kelompok P2, P3, P4. Kelompok P2, P3 tidak berbeda nyata $(p>0,05)$ dengan $\mathrm{P} 1, \mathrm{P} 4$, hasil rata-rata titer antibodi yang dihasilkan P2 dan P3 sama namun 
lebih rendah dibandingkan P1. Kelompok P4 memiliki rata-rata titer antibodi yang lebih tinggi dibandingkan P1, P2, P3.

Berdasarkan analisis hasil penelitian kelompok P0 menunjukkan rata-rata titer antibodi yang dihasilkan 0,3-0,5 $\log 2$, hal ini karena P0 merupakan kelompok tanpa perlakuan ekstrak buah pare dan vaksin.

Tabel 1. Titer antibodi ayam broiler umur 35 hari dan 49 hari

\begin{tabular}{ccc}
\hline Perlakuan & $\begin{array}{c}\text { Titer Antibodi 35 hari }(\log 2) \\
\text { Rata-rata } \pm \text { Standar Deviasi }\end{array}$ & $\begin{array}{c}\text { Titer Antibodi 49 hari (log 2) } \\
\text { Rata-rata } \pm \text { Standar Deviasi }\end{array}$ \\
\hline P0 & $0,50^{\mathrm{a}} \pm 0,527$ & $0,30^{\mathrm{a}} \pm 0,483$ \\
P1 & $6,60^{\mathrm{b}} \pm 1,429$ & $7,90^{\mathrm{bc}} \pm 1,449$ \\
P2 & $6,60^{\mathrm{b}} \pm 1,074$ & $7,30^{\mathrm{b}} \pm 0,483$ \\
P3 & $6,60^{\mathrm{b}} \pm 1,173$ & $7,30^{\mathrm{b}} \pm 1,337$ \\
P4 & $7,20^{\mathrm{b}} \pm 0,788$ & $8,80^{\mathrm{c}} \pm 1,032$ \\
\hline
\end{tabular}

Keterangan: (P0) Kontrol negatif atau tanpa perlakuan; (P1) Kontrol positif atau hanya vaksin saja;

(P2) Vaksin+dosis ekstrak buah pare $150 \mathrm{mg} / \mathrm{L}$; (P3) Vaksin+dosis ekstrak buah pare $300 \mathrm{mg} / \mathrm{L}$; (P4) Vaksin+dosis ekstrak buah pare $450 \mathrm{mg} / \mathrm{L}$

Penurunan titer antibodi yang terjadi pada kelompok yang tidak divaksinasi disebabkan oleh menurunnya titer antibodi asal induk didalam tubuh ayam. Hal ini sesuai dengan pernyataan Indriani dan Darminto (2000) yaitu antibodi asal induk akan turun secara linier seiring bertambahnya umur. Kelompok P1, P2, P3 dan P4 peningkatan titer antibodi pasca vaksinasi ND kedua (booster) terjadi peningkatan dari hasil vaksinasi pertama. Hal ini karena menurut Tizard (1982), sistem pembentukan antibodi memiliki kemampuan untuk mengingat keterpaparan dengan suatu antigen sebelumnya. Pada vaksinasi kedua atau dosis antigen yang berbeda dengan pertama, titer antibodi akan mencapai tingkat yang lebih tinggi karena tubuh sudah mengenal antigen yang masuk ke dalam tubuhnya sehingga respon kekebalan tubuh lebih tinggi, demikian antibodi pasca vaksinasi ND.

Berdasarkan hasil analisis dari kelompok perlakuan vaksin dan ekstrak buah pare yang diberi dosis $150 \mathrm{mg} / \mathrm{L}, 300 \mathrm{mg} / \mathrm{L}$ dan $450 \mathrm{mg} / \mathrm{L}$ tidak berbeda nyata dengan kelompok perlakuan yang hanya divaksin saja. Beberapa faktor yang dapat mempengaruhi adanya titer antibodi yang dihasilkan diantaranya dosis, dan tingkat kebal individu yang berbeda. Dosis yang rendah tidak dapat merangsang sel sel imunokompeten. Variasi tanggap kebal tiap individu yang berbeda akan mempengaruhi kekebalan yang dihasilkan. Individu yang menanggapi vaksinasi dengan baik akan menunjukkan kekebalan yang dapat melindungi dan individu dengan tanggap kebal lemah kurang mampu membentuk titer yang dapat melindungi. Antigen yang berada lama di dalam tubuh akan menghasilkan tanggap kebal lebih lama. Sel peka antigen akan menanggapi dengan memproduksi antibodi jika titer antigen dan cara infeksi yang sesuai (Siregar, 2009).

Efek imunomodulator pada buah pare umumnya sesuai dengan pendapat Saifulhaq (2009), yang menyatakan bahwa penelitian secara laboratoris kandungan senyawa flavonoid dapat meningkatkan produksi IL-2, meningkatkan proliferasi dan diferensiasi limfosit sel T, sel B, sel NK serta menunjukkan kemampuan dalam memberikan efek imunostimulan pada manusia dan hewan (meningkatkan produksi sel interferon dan aktivitas sel NK) (Gupta et al., 2011). Interferon dapat membantu dalam presentasi antigen dan memiliki peranan dalam imunitas humoral. Peran imunoregulasi dari interferon adalah kemampuannya dalam mempromosi fase induktif dari respon imun. IFN terlibat dalam pembentukan dan presentasi peptida antigenik dipermukaan sel dan juga mempunyai kemampuan yang unik dalam meregulasi ekspresi molekul MHC kelas II, sehingga dapat 
meningkatkan respon dari sel limfosit ThCD4 ${ }^{+}$. Induksi ekspresi molekul MHC kelas II oleh IFN terjadi berbagai macam sel, diantaranya sel fagosit mononuklear, sel endotel dan sel epitel. IFN menghambat ekskresi molekul MHC kelas II di permukaan sel B yang bersifat IL-4dependent dan memegang peran kunci dalam pemrosesan antigen intraseluler menjadi bentuk peptide antigenik sebelum diekskresikan kepermukaan sel bersama molekul MHC. Modifikasi aktivitas proestom, yaitu suatu subunit komplek enzim yang bertanggung jawab atas proses terjadinya peptide yang kemudian berikatan dengan molekul MHC kelas 1 (Wiedosari, 2007).

Beberapa faktor lain yang dapat membantu peningkatan titer antibodi diantaranya pemenuhan kebutuhan pakan, pemeliharaan yang baik, vaksin, lingkungan. Faktor - faktor produksi tersebut merupakan kesatuan sistem, apabila salah satu faktor terabaikan atau kurang mendapat perhatian maka penanganan terhadap faktor yang lain tidak dapat memberikan hasil yang maksimal. Pemeliharaan yang baik juga akan tercipta lingkungan yang baik. Lingkungan juga merupakan faktor yang sangat berpengaruh terhadap sitem kekebalan ayam broiler (Chorpra and Robert, 2001).

\section{KESIMPULAN}

Pemberian ekstrak buah pare tidak berpengaruh nyata terhadap titer antibodi ayam yang divaksin Newcastle disease.

\section{UCAPAN TERIMA KASIH}

Peneliti mengucapkan terima kasih kepada PSDKU Banyuwangi Universitas Airlangga atas izin yang diberikan dan fasilitas untuk melaksanakan penelitian.

\section{DAFTAR PUSTAKA}

Adi, A.A., N.M. Astawa, K.S. Putra, Y. Hayashi, and Y. Matsumoto. 2010. Isolation And Characterization of a Pathogenic Newcastle
Disease Virus From a Natural Case in Indonesia. Vet Med Sci, 72: 313-319.

Chopra, I. and M. Robert. 2001. Tetracycline Antibiotic: mode in action, application, moleculer biology, and epidemiology of bacterial resistances. Microbiol $\mathrm{Mol}$ Biol Rev, 62: 232-260.

Chunthorng-Orn, J., S. Panthong, and A. Itharat. 2012. Antimicrobial, Antioxidant Activities and Total Phenolic Content of Thai Medicinal Plants Used to Treat HIV Patients. J Med Assoc Thai, 95(1): 154-158.

Dharmayanti, N.L.P.I., R. Hartawan, D.A. Hewajuli, and R. Indriani. 2014. Phylogenetic analysis of genotype VII of new castle disease virus in Indonesia. Afric $J$ Microbiol Res, 8(13): 1368-1374.

Fang, E.F., C.Z. Zhang, T.B. Ng, J.H. Wong, W.L. Pan, and X.J. Ye. 2012. Momordica charantia Lectin, A Type II Ribosome Inactivating Protein, Exhibits Antitumor Activity Toward Human Nasopharyngeal Carcinoma Cells in Vitro And in Vivo. Cancer Prev Res (Phila), 5: 109-121.

Gupta, P., S. Kalpara, and S. Avinash. 2011. Isolation of Cellulose Degrading Bacteria Determination of Their Cellulolytic potential. Int J Microbiol.

Indriani, R., Darmianto. 2000. Penyakit Infectious Bronchitis pada ayam dan cara mengendalikannya. Wartazoa, 5(2): 65-72.

Miller, PJ., C.L. Afonso, E. Spackman, M.A. Scott, J.C. Pedersen, D.A. Senne, J.D. Brown, C.M. Fuller, M.M. Uhart, W.B. Karesh, I.H. Brown, D.J. Alexander, \& D.E. Swayane. 2010. Evidence for a New Avian Paramyxovirus Serotype-10 Detected in Rockhopper Penguins from the Falkland Islands. J Virol, 84(21): 11496-11504. 
Patti, J.M., D.J. King, C.L. Afonso, \& D.L. Suarez. 2007. Antigenic Differences Among Newcastle Disease Virus Strains Of Different Genotypes Used In Vaccine Formulation Affect Viral Shedding After A Virulent Challenge. Vaccine, 25: 7238-7246.

Saifulhaq, M. 2009. Pengaruh pemberian Ekstrak Buah Mahkota Dewa Dosis Bertingkat Terhadap Proliferasi Limfosit Lien pada Mencit BALB/C. Biomedika1, 2: 33.

Shunlin, H., H. Ma, Y. Wu, W. Liu, X. Wang, Y. Liu, \& X. Liu. 2009. A vaccine candidate of attenuated genotype VII Newcastle disease virus generated by reverse genetics. Vaccine, 27: 904-910.

Siregar, C.J. 2009. Gambaran respon kebal terhadap Infectious Bursal Disease (IBD) pada ayam pedaging yang divaksin IBD killed setengah dosis dan ditantang dengan virus IBD [Skripsi]. Bogor (ID): Institut Pertanian Bogor.

Tabbu, C.R. 2000. Penyakit Ayam dan Penanggulangannya: Penyakit Bakterial, Mikal, dan Viral. Kanisius, Yogyakarta.

Tizard I. 1982. Pengantar imunologi veteriner. M. Partodiredjo, penerjemah. Edisi ke-2. Surabaya: Airlangga University Press.

Wiedosari, Ening. 2017. Peranan Imunomodulator Alami (Aloe vera) dalam Sistem Imunitas Seluler dan Humoral. Bogor: Balai Besar Penelitian Veteriner, Hal.168.

Xiao, S., A. Paldurai, B. Nayak, A. Samuel, E.E. Bharoto, T.Y. Prajitno, P.L. Collins, \& S.K. Samala. 2012. Complate Genome Sequences of Newcastle Disease Virus Strain Circulating in Chicken Population of Indonesia. $J$ Virol, 86: 5969-5970. 